\title{
Acidovorax citrulli Seed Inoculum Load Affects Seedling Transmission and Spread of Bacterial Fruit Blotch of Watermelon Under Greenhouse Conditions
}

\author{
B. Dutta and H. Scherm, Department of Plant Pathology, University of Georgia, Athens 30602; R. D. Gitaitis, Department of Plant \\ Pathology, Coastal Plain Experiment Station, University of Georgia, Tifton 31793; and R. R. Walcott, Department of Plant Pathology, \\ University of Georgia, Athens
}

Abstract

Dutta, B., Scherm, H., Gitaitis, R. D., and Walcott, R. R. 2012. Acidovorax citrulli seed inoculum load affects seedling transmission and spread of \begin{abstract}
bacterial fruit blotch of watermelon under greenhouse conditions. Plant Dis. 96:705-711.
Infested seed are typically the primary source of inoculum for bacterial fruit blotch (BFB) of cucurbits. An inoculum threshold of 1 infested seed per 10,000 seeds is widely used in seed health testing for Acidovorax citrulli. However, the influence of seed inoculum load on BFB seedling transmission has not been elucidated. In this study, watermelon seedlots (128 seeds/lot) containing one seed inoculated with $A$. citrulli at levels ranging from $1 \times 10^{1}$ to $1 \times 10^{7} \mathrm{CFU}$ were used to investigate the effect of seed inoculum load on seedling transmission and spatiotemporal spread of BFB under greenhouse conditions. The relationship between $A$. citrulli seed inoculum load and frequency of BFB seedling transmission followed a sigmoidal pattern $\left(R^{2}=0.986, P\right.$ $=0.0047$ ). In all, 100 and $96.6 \%$ of seedlots containing one seed with 1 $\times 10^{7}$ and $1 \times 10^{5} \mathrm{CFU}$ of $A$. citrulli, respectively, transmitted the pathogen to seedlings; in contrast, the proportion of seedlots that yielded BFB-infected seedlings was lower for lots with one seed infested with $1 \times 10^{3}(46.6 \%)$ and $1 \times 10^{1}(16.7 \%)$ CFU of A. citrulli. The relationship between $A$. citrulli seed inoculum load and frequency of pathogen detection in seedlots using immunomagnetic separation
\end{abstract}

combined with a real-time polymerase chain reaction assay also followed a sigmoidal pattern $\left(R^{2}=0.997, P=0.0034\right)$. Whereas $100 \%$ of samples from seedlots $(10,000$ seeds/lot $)$ with one seed containing $\geq 1$ $\times 10^{5} \mathrm{CFU}$ tested positive for A. citrulli, $75 \%$ of samples from lots with one seed containing $1 \times 10^{3} \mathrm{CFU}$ tested positive for the pathogen, and only $16.7 \%$ of samples with one seed containing $10 \mathrm{CFU}$ tested positive. Because disease transmission was observed for lots with just one seed containing $10 \mathrm{~A}$. citrulli $\mathrm{CFU}$, zero tolerance for seedborne $A$. citrulli is recommended for effective BFB management. The seedling transmission experiments also revealed that temporal spread of BFB in 128-cell seedling trays increased linearly with $A$. citrulli inoculum load $\left(r^{2}=0.976, P=0.0037\right)$. Additionally, the frequency of spatial spread of BFB from an inoculated seedling in the center of a planting tray to adjacent healthy seedlings over one-, two-, or three-cell distances was greater for lots with one seed infested with at least $1 \times 10^{5} \mathrm{CFU}$ than for lots with one seed infested at lower inoculum loads $\left(1 \times 10^{1}\right.$ and 1 $\times 10^{3} \mathrm{CFU} /$ seed).
Bacterial fruit blotch (BFB) is an economically important disease of cucurbits, including watermelon (Citrullus lanatus) $(27,36)$. The disease is caused by the gram-negative bacterium Acidovorax citrulli (formerly Acidovorax avenae subsp. citrulli $=$ Pseudomonas pseudoalcaligenes subsp. citrulli) $(28,30,40)$. In the United States, BFB was first observed in commercial watermelon fields in Florida in 1989 (33). Since then, the disease has caused significant economic losses to watermelon seed, transplant, and fruit production worldwide $(2-4,10,12,14,17,18,32,33)$. Epidemiologically, infested seed are the most important source of primary inoculum for BFB $(17,22,34,39)$. Once the pathogen is introduced into transplant houses via infested seed, high humidity, high temperature, and overhead irrigation increase the risk of BFB epidemic development. Hence, strategies to exclude A. citrulli from seed and transplants are critical for minimizing the threat of BFB.

Currently, seed health testing and seed treatments are employed routinely for BFB management $(1,11-13)$. However, neither strategy guarantees pathogen-free seed. The accuracy and precision of seed health testing for $A$. citrulli is influenced by many factors, including sample size, sampling method, and pathogen extraction efficiency (19-21). The effectiveness of seed health testing is also influenced by the seed inoculum threshold, which is the level of seed inoculum that will lead to disease development and economic losses when seed are planted under conducive field conditions. Inoculum threshold is also defined as the level of seedborne inocu-

Corresponding author: R. R. Walcott, E-mail: rwalcott@uga.edu

Accepted for publication 19 November 2011.

http://dx.doi.org/10.1094/PDIS-04-11-0292

(C) 2012 The American Phytopathological Society lum that leads to an unacceptable risk of disease $(25,26)$. For disease management based on pathogen exclusion via seed health testing, it is critical to determine the seed inoculum threshold experimentally. In practice, the factors that influence the inoculum threshold are numerous and include pathogen aggressiveness, host susceptibility, and environmental conditions (7). As a result, inoculum thresholds are difficult to establish and have been determined for only a few bacterial diseases, including black rot of crucifers (caused by Xanthomonas campestris pv. campestris) and bacterial blight of carrot (caused by $X$. hortorum pv. carotae) $(29,35)$. To date, an inoculum threshold has not been determined for BFB. Instead, a threshold of 1 infested seed per 10,000 seeds has been adopted based on research on black rot of crucifers (29). According to Gitaitis and Walcott (7), a sample of 30,000 to 50,000 seeds/lot must be tested to guarantee 95 and $99 \%$ confidence, respectively, at detecting 1 infested seed in a sample of 10,000 seeds. However, this inoculum threshold does not consider seed inoculum load (inoculum concentration in CFU per seed), even though pathogen population can influence aspects of seed-to-seedling transmission, particularly the incubation period $(6,15,23)$.

Despite acceptance as the industry standard, the seedling growout assay for A. citrulli seed health testing has limitations (1). Although the assay is technically simple and based on visual inspection of seedlings, it is expensive because of greenhouse space and technical labor requirements. The effectiveness of the seedling grow-out assay is dependent on the rate of seed-to-seedling transmission of the pathogen, which depends on environmental conditions in the greenhouse. The assay can take up to 3 weeks to complete and requires trained technicians to recognize variations in BFB seedling symptoms depending on host-strain interactions. Finally, laboratory assays (e.g., serological tests and polymerase chain reaction [PCR] assays) are required to confirm the identity of bacteria recovered from seedlings. Walcott et al. (38) reported that 
the greenhouse seedling grow-out assay detected only 12.5 and $37.5 \%$ of seedlots $(10,000$ seeds/lot) with 0.01 and $0.1 \%$ infested seed, respectively. In comparison, immunomagnetic separation (IMS) combined with the PCR assay (IMS-PCR) yielded detection frequencies of 25.2 and $87.5 \%$ for inoculated watermelon seedlots (10,000 seeds/lot) with 0.01 and $0.1 \%$ A. citrulli-infested seed, respectively (37). Although the differences in detection frequencies for the IMS-PCR assay and seedling grow-out assay were not statistically significant, the data demonstrated the potential of the IMS-PCR assay as an effective alternative to the grow-out assay for $A$. citrulli seed health testing.

The goal of this research was to determine the effect of seed inoculum load on seedling transmission and the spread of BFB in watermelon seedlings in the greenhouse. Because an effective seed health assay must display a pathogen detection threshold that is lower than the seed inoculum threshold for a given disease $(16,25)$, and the BFB inoculum threshold had not been previously determined, we also sought to determine this parameter for A. citrulli under greenhouse conditions.

\section{Materials and Methods}

Bacterial strain and inoculum preparation. A. citrulli strain AAC00-1 (38), used in this study, was recovered from a natural BFB outbreak in watermelon crops in Georgia in 1992. The strain was stored in $15 \%$ glycerol at $-80^{\circ} \mathrm{C}$, and cultured on nutrient agar for $48 \mathrm{~h}$ at $28^{\circ} \mathrm{C}$ as needed. To prepare inoculum, $3 \mathrm{ml}$ of nutrient broth in a test tube was inoculated with a single colony of AACO01 from a 48 -h culture and incubated overnight at $30^{\circ} \mathrm{C}$ on a rotary shaker (Innova; New Brunswick Scientific, Edison, NJ) at $250 \mathrm{rpm}$ After $24 \mathrm{~h}$, the culture was centrifuged at $4,000 \times \mathrm{g}$ for $5 \mathrm{~min}$ (Allegra 25R; Beckman Coulter, Fullerton, CA), the supernatant was decanted, and the pellet was resuspended in $1 \mathrm{ml}$ of $0.1 \mathrm{M}$ phosphate-buffered saline (PBS). Bacterial concentration was estimated using a spectrophotometer (Spectronic 20; Bausch and Lomb, Rochester, NY) and adjusted to the desired concentration (optical density of 0.3 at $600 \mathrm{~nm}=$ approximately $1 \times 10^{8} \mathrm{CFU} / \mathrm{ml}$ ) with sterile PBS. The bacterial suspension was concentrated 10fold by centrifugation, and 10 -fold serial dilutions were generated from suspensions containing $1 \times 10^{3}, 1 \times 10^{5}, 1 \times 10^{7}$, and $1 \times 10^{9}$ $\mathrm{CFU} / \mathrm{ml}$.

Seed inoculation. Watermelon seed of 'Crimson Sweet' (Hollar Seeds, Rocky Ford, CO) were inoculated individually to achieve final levels of AAC00-1 inoculum of $1 \times 10^{1}, 1 \times 10^{3}, 1 \times 10^{5}$, and $1 \times 10^{7} \mathrm{CFU} /$ seed. Each seed was first incised at the micropylar end with a sterile scalpel with a number 3 blade (DR Instruments, Palos Hills, IL). A sterile teasing needle (DR Instruments) was then used to make a shallow hole through the testa at the chalazal end of each seed. With a Pasteur pipette attached to a vacuum line, approximately $10 \mu \mathrm{l}$ of bacterial suspension $\left(1 \times 10^{3}, 1 \times 10^{5}, 1 \times\right.$ $10^{7}$, and $1 \times 10^{9} \mathrm{CFU} / \mathrm{ml}$ ) was aspirated into each seed as follows. Using a vacuum, each seed was attached to the Pasteur pipette at the puncture wound at the chalazal end. Inoculum $(10 \mu \mathrm{l})$ was deposited on a sterile petri dish lid, and the vacuum was used to draw the cell suspension into the seed via the wound at the micropylar end. Seed inoculated with PBS were used as a negative control treatment. Inoculated seed were air dried at room temperature overnight. Before seed inoculation, the inoculum concentration in each bacterial suspension was verified by spread-plating one $100-\mu$ l aliquot for each 10 -fold serial dilution onto proprietary Nunhem's semiselective agar medium (Nunhems Seed Company, Haelen, The Netherlands). Furthermore, immediately following inoculation, the A. citrulli populations present in each seed were confirmed. Five inoculated seeds were crushed individually in 1 $\mathrm{ml}$ of sterile PBS, and one 100- $\mu$ l aliquot of each 10-fold serial dilution of each seed macerate was spread-plated onto Nunhem's agar medium. After incubation at $28^{\circ} \mathrm{C}$ for 4 to 5 days, A. citrulli colonies were enumerated and CFU per seed estimated. The efficiency of the seed inoculation protocol was estimated as $\left(\log _{10}\right.$ A. citrulli $\mathrm{CFU}$ recovered/seed $/ \log _{10}$ A. citrulli $\mathrm{CFU}$ applied/seed) $\times 100(24)$.
Effect of $A$. citrulli seed inoculum load on BFB seedling transmission and spread of $\boldsymbol{A}$. citrulli. Humidity chambers were constructed in a greenhouse to generate conditions conducive for BFB development. Each humidity chamber ( 4.5 by 1.0 by $1.0 \mathrm{~m}$ ) was supported by a frame of PVC pipes and covered with transparent plastic (6-Mil clear polyethylene sheeting; Norkan, Warren, $\mathrm{MI})$. Inside each chamber, high relative humidity (RH) was maintained using a humidifier (Trion 707U, Indian Trail, NC), and temperature and RH were monitored using data loggers (WatchDog 250; Spectrum Technologies, East Plainfield, IL). Throughout the study, the mean environmental conditions in the chambers were 25.4 to $28.0^{\circ} \mathrm{C}$ and 76.2 to $80.0 \% \mathrm{RH}$.

To investigate the effect of seed inoculum load on seedling transmission, each inoculated seed was placed at the center of a 128-cell tray (Speedling, Sun City, FL) surrounded by noninoculated seed. Each seedlot was limited to 128 seeds because of space limitations in the humidity chambers. Additionally, this sample size allowed multiple replicates of each treatment to be tested that would not have been possible with larger seedlots. Trays were filled with finegrade composted pine bark mixed with vermiculite in a 3:1 ratio. A randomized complete block design was employed, with the experimental unit being one seedlot in a 128-cell tray. In each of three independent experiments, treatments (the five levels of $A$. citrulli inoculum per seed noted above) were arranged in 10 replicate blocks, with trays arranged contiguously. Manual watering (rather than automated overhead irrigation) was used to reduce the risk of cross-contamination among treatments from splash dispersal of bacteria. This was done by carefully directing a gentle stream of water from a hose at the base of the plants instead of onto the foliage.

A seedlot was considered to have transmitted the disease when the inoculated seedling in a tray developed typical BFB symptoms (water soaking on the abaxial surface of cotyledons). The frequency of BFB seedling transmission for each treatment was recorded every 3 days for 18 days after planting. The mean frequency of BFB seedling transmission was calculated as [(number of seedlots with at least one seedling with BFB symptoms)/(total number of seedlots planted)] $\times 100$ for each treatment. The relationship between $A$. citrulli seed inoculum load and frequency of BFB seedling transmission was determined by regression analysis using SigmaPlot (version 10.0; Systat, San Jose, CA). The regression analysis was based on means from the three experiments after a preliminary analysis of variance (PROC GLM in SAS, version 9.1; SAS Institute, Cary, NC) showed no significant effect of the experiment factor at $P=0.05$. To determine the effect of $A$. citrulli seed inoculum load on temporal spread of BFB among seedlings, the average rate of BFB development was calculated as (number of symptomatic seedlings)/(total number of seedlings)/(18 days) for each treatment on the final day of the experiment. Linear regression analysis was used to determine the relationship between A. citrulli seed inoculum load and mean rate of BFB development.

Effect of $A$. citrulli seed inoculum load on BFB spatial spread. In the BFB transmission experiment described above, the location of each symptomatic seedling within each 128-cell tray was recorded at 3-day intervals for 18 days after inoculation to determine the effect of $A$. citrulli seed inoculum load on spatial spread of BFB among seedlings. Spread was quantified as the cumulative number of across-cell transmission events of BFB symptoms from the seedling that developed from an inoculated seed to adjacent seedlings over one-, two-, or three-cell distances. Linear regression analysis was used to determine the relationship between $A$. citrulli seed inoculum load and the mean cumulative number of across-cell transmission events for each seed inoculum level. The regression analysis was based on means from the three experiments after a preliminary analysis of variance showed no significant effect of the experiment factor at $P=0.05$.

Confirmation of BFB on symptomatic seedlings. To confirm that the symptoms observed on seedlings were caused by $A$. citrulli, bacterial isolations were performed from at least five seedlings from each treatment. Small (2 to $4 \mathrm{~mm}^{2}$ ) pieces of sympto- 
matic tissue were macerated in $200 \mu \mathrm{l}$ of sterile PBS, streaked onto Nunhem's agar, and incubated for 5 days at $28^{\circ} \mathrm{C}$. After incubation, round, red colonies with smooth margins were putatively identified as A. citrulli. For further confirmation, genomic DNA was extracted from two or three colonies per isolation and tested with a TaqMan real-time PCR assay using A. citrulli-specific primers (9).

Risk of BFB epidemic development from asymptomatic seedlings in the field. In the above-mentioned greenhouse transmission experiments, some of the seedlings that developed from seed inoculated with $0,1 \times 10^{1}$, and $1 \times 10^{3} \mathrm{CFU}$ did not develop BFB symptoms during the 18-day experiment. To determine whether asymptomatic watermelon seedlings exposed to A. citrulli BFB in the greenhouse posed a risk for disease development in the field, asymptomatic seedlings from each of these three inoculation treatments were transplanted into field plots at the Black Shank Farm at the University of Georgia Tifton Campus in July 2008 (with seedlings from the second run of the greenhouse experiment) and April 2009 (using seedlings from the third experiment). The plants were then monitored for disease development. For each of the three inoculum levels, five replicates of five asymptomatic seedlings (that developed from inoculated seed at the center of the tray, along with four adjacent seedlings) were utilized, giving a total of 15 fiveplant plots/year. Seedlings were transplanted into raised, plasticcovered beds with drip irrigation and a plant spacing of one seedling per $4 \mathrm{~m}^{2}$. To prevent bacterial spread between plots, a 6-mlong section of bed was left fallow on both sides of each plot. Routine fungicide applications were made to control fungal diseases and downy mildew. To manage gummy stem blight caused by Didymella bryoniae, plants were sprayed every 5 days with chlorothalonil, Daconil 2787 at 3.52 liters/ha (Syngenta Crop Protection, Greensboro, NC) + difenoconazole, Dividend at $525 \mathrm{ml} / \mathrm{ha}$ (Syngenta Crop Protection) + cyprodinil, Vangard at $525 \mathrm{ml} / \mathrm{ha}$ (Syngenta Crop Protection). At vine run, azoxystrobin, Quadris at 1.2 liters/ha (Syngenta Crop Protection) was applied to manage belly rot. At fruit set, flupicolide, Infinito at $300 \mathrm{ml} / \mathrm{ha}$ (Valent Agricultural Products, Walnut Creek, CA) and mancozeb, Dithane M-45 at $125 \mathrm{ml} / \mathrm{ha}$ (DowAgroSciences, Indianapolis, IN) plus metalaxyl, Apron at $210 \mathrm{ml} / \mathrm{ha}$ (Ciba-Geigy Corp., Greensboro, NC) were sprayed biweekly to manage downy mildew. For fertilization, calcium nitrate was side dressed at $182 \mathrm{~kg} / \mathrm{ha}$. In the two field trials, plots were observed visually for BFB incidence (both foliar and fruit symptoms) at 20- to 25-day intervals for 70 days after transplanting and again at harvest ( 85 days after transplanting).

Effect of seed inoculum load on detection of $A$. citrulli by IMS real-time PCR assay. Seedlots were generated by mixing 1 watermelon seed (Crimson Sweet) inoculated with different concentrations of A. citrulli $\left(1 \times 10^{1}, 1 \times 10^{3}, 1 \times 10^{5}\right.$, or $1 \times 10^{7} \mathrm{~A}$. citrulli CFU, as described above) with 10,000 noninfested seed. Seed inoculated with PBS and mixed with 10,000 noninfested seeds served as negative control lots. Each seedlot was tested by IMS real-time PCR assay as described previously $(35,38)$. Briefly, seed were shaken in 1 liter of PBS buffer for $1 \mathrm{~h}$ in a sterile 2-liter side-arm flask attached to a vacuum line. A vacuum was drawn and interrupted abruptly at 15-min intervals to aid extraction of bacteria from under the testae. During the extraction process, seed were agitated continuously using a magnetic stir bar and a stirring plate. After extraction, the seed wash was passed through two layers of cheesecloth to remove seed, filtered through one layer of Whatman number 1 filter paper, and centrifuged at $13,800 \times g$ for $15 \mathrm{~min}$. The supernatant was decanted and the pellet resuspended in $6 \mathrm{ml}$ of PBS-bovine serum albumin (BSA). For IMS, $2.5 \times 10^{7} \mathrm{immu}-$ nomagnetic beads (IMBs) coated with $40 \mu \mathrm{g}$ of anti-AAC antibody per $10^{8}$ IMBs were used for each sample. Immunomagnetic separation was conducted on each sample for $1 \mathrm{~h}$ at $4^{\circ} \mathrm{C}$ with constant agitation. After rinsing three times with PBS-BSA and once with deionized distilled water, IMBs were resuspended in $30 \mu \mathrm{l}$ of sterile deionized water. Captured cells were lysed by boiling for 10 min to release genomic DNA $(37,38)$ and a $5-\mu l$ sample of eluted DNA was tested by real-time PCR assay using a species-specific
TaqMan assay, as described previously (9). Cycle threshold (Ct) values were recorded for each sample. Four replications of each treatment were assayed and each experiment was repeated four times. The mean frequency of $A$. citrulli detection was determined as [(number of positive detections for each treatment)/(total number of seedlots tested for each treatment) $] \times 100$. Regression analysis was conducted to determine the relationship between $A$. citrulli seed inoculum load and detection of infested seedlots. The regression analysis was based on means from the four experiments after a preliminary analysis of variance showed no significant effect of the experiment factor at $P=0.05$.

A. citrulli seed inoculum threshold. To estimate the $A$. citrulli seed inoculum threshold (seed inoculum level that could be detected reliably by IMS real-time PCR assay and that displayed the lowest frequency of BFB seedling transmission), the frequency of detection of A. citrulli-infested lots was plotted against the frequency of BFB seedling transmission for different seed inoculum loads, analogous to a receiver operating characteristic (ROC) curve (41). This was done using mean values from the three experiments. The point closest to the theoretical optimum of no transmission and $100 \%$ detection was determined visually.

\section{Results}

Efficiency of seed inoculation method. The efficiency of the seed inoculation method calculated for inoculum levels of $1 \times 10^{3}$, $1 \times 10^{5}$, and $1 \times 10^{7} \mathrm{CFU} /$ seed was $93.5 \pm 2.5,92.0 \pm 0.8$, and 98.0 $\pm 3.1 \%$ (mean \pm standard error), respectively (Table 1 ). In contrast, A. citrulli was not recovered from seed inoculated with $1 \times 10^{1}$ CFU of $A$. citrulli by plating the seed macerate on a semiselective agar medium. Hence, the inoculation efficiency for this treatment was $0 \%$.

Effect of $A$. citrulli seed inoculum load on frequency of BFB transmission and temporal disease dynamics. The mean frequencies of BFB seedling transmission for seed lots (128 seeds/lot) with 1 seed inoculated with $1 \times 10^{1}, 1 \times 10^{3}, 1 \times 10^{5}$, and $1 \times 10^{7}$ CFU were 16.7, 46.6, 96.6, and 100\%, respectively (Fig. 1). Linear and nonlinear regression curves were fitted, and the relationship between A. citrulli seed inoculum load and frequency of BFB transmission was described best by a two-parameter sigmoidal model $\left(R^{2}=0.986 ; P=0.0047\right)$. In contrast, a linear regression model fitted to this relationship was not statistically significant $(P$ $=0.067$ ). As expected, control seedlots with $0 \mathrm{CFU}$ did not yield symptomatic seedlings. A subset of seedlings associated with each treatment that led to putative BFB symptoms was confirmed to be infected with $A$. citrulli by pathogen isolation followed by realtime PCR assays (data not shown).

The relationship between $A$. citrulli seed inoculum load and mean rate of BFB development over time was linear $\left(r^{2}=0.976 ; P\right.$ $=0.0037$; Fig. 2). BFB symptoms did not develop on seedlings from negative control lots composed of 1 seed treated with PBS

Table 1. Efficiency of the watermelon seed inoculation protocol with different levels of Acidovorax citrulli inoculum used to assess seed transmission of the pathogen under greenhouse conditions

\begin{tabular}{|c|c|c|}
\hline $\begin{array}{l}\text { Mean } \log _{10}(\mathrm{CFU} \text { of } \\
\text { A. citrulli/ml }) \text { inoculated } \\
\text { into each seed }\end{array}$ & 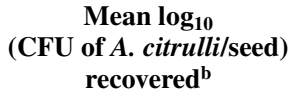 & $\begin{array}{l}\text { Efficiency of } \\
\text { recovery } \\
(\%)^{c}\end{array}$ \\
\hline $7.51 \pm 0.58$ & $7.36 \pm 0.38$ & $98.0 \pm 3.05$ \\
\hline $5.65 \pm 0.67$ & $5.20 \pm 0.82$ & $92.0 \pm 0.76$ \\
\hline $3.70 \pm 0.45$ & $3.46 \pm 0.75$ & $93.5 \pm 2.06$ \\
\hline $1 \pm 0.47$ & 0 & 0 \\
\hline 0 & 0 & $\ldots$ \\
\hline
\end{tabular}

a Values represent mean $\log _{10} \mathrm{CFU}$ of $A$. citrulli/ml \pm standard error of five replicates from each inoculum concentration determined spectrophotometrically.

b Values represent mean $\log _{10}$ CFU of $A$. citrulli per seed \pm standard error of five replicates from each inoculated seed determined by dilution-plating onto semiselective medium.

${ }^{\mathrm{c}}$ Efficiency $=\left[\left(\log _{10} \mathrm{CFU} / \mathrm{seed}\right.\right.$ of $A$. citrulli recovered $) /\left(\log _{10} \mathrm{CFU} / \mathrm{ml}\right.$ of A. citrulli inoculated) $] \times 100$. 
instead of $A$. citrulli and planted with 127 noninfested seeds. The mean rate of BFB development for lots with one infested seed containing $1 \times 10^{1}, 1 \times 10^{3}, 1 \times 10^{5}$, or $1 \times 10^{7} \mathrm{CFU}$ was 0.0004 , 0.0012, 0.0020, and 0.0023/day, respectively (Fig. 2).

Effect of $A$. citrulli seed inoculum load on BFB spatial spread among seedlings. The relationship between A. citrulli seed inoculum load and secondary BFB spread among seedlings (over one-, two-, and three cell-distances) was linear $\left(r^{2} \geq 0.91 ; P \leq 0.005\right)$. As expected, BFB seedling transmission and secondary spread were not observed for the negative control treatments in any repeat of the experiment. As A. citrulli seed inoculum load increased, so too did BFB spatial spread in terms of cumulative transmission over one-, two-, and three-cell distances from the seedling that developed from the inoculated seed (Fig. 3). With regards to BFB seedling-to-seedling transmission across a one-cell distance, the higher the $A$. citrulli seed inoculum load, the greater the number of disease transmission events. The relationship between $A$. citrulli seed inoculum load and BFB transmission across a one-cell distance was linear $\left(r^{2}=0.954 ; P<0.005\right.$; Fig. 3A). A positive linear relationship was also observed between $A$. citrulli seed inoculum load

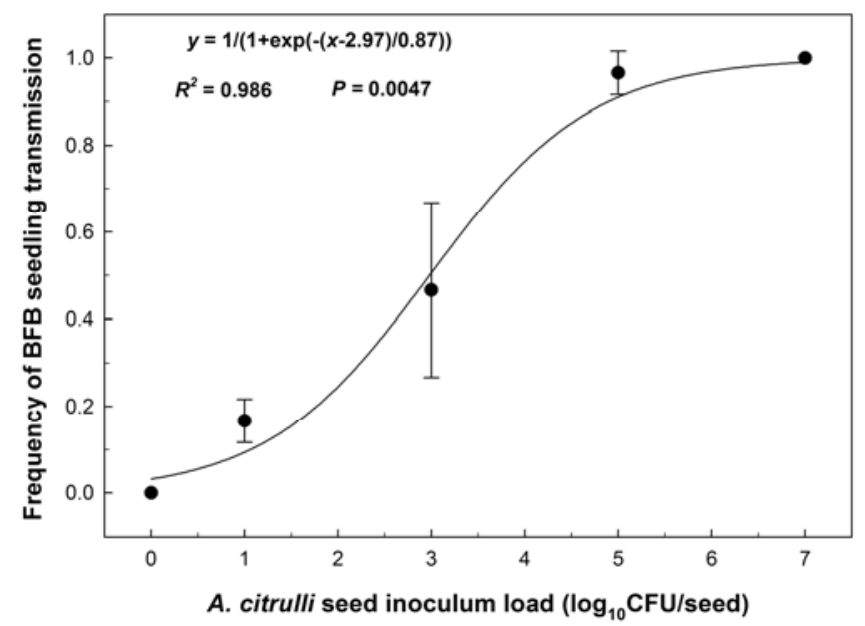

Fig. 1. Nonlinear regression analysis of Acidovorax citrulli inoculum load per seed versus bacterial fruit blotch (BFB) seedling transmission frequency over 18 days. Single seeds were inoculated with $A$. citrulli at concentrations ranging from 0 to $1 \times$ $10^{7} \mathrm{CFU}$. Each seed was planted in the center of a 128-cell tray with 127 noninfested seeds. Each data point represents the mean frequency of BFB seedling transmission for 10 replicates across three independent experiments $(n=30)$.

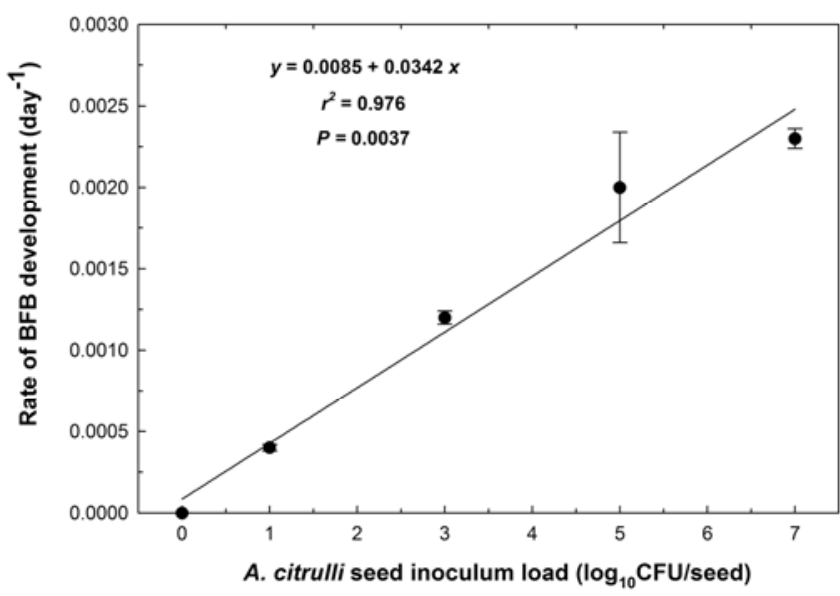

Fig. 2. Linear regression analysis of the temporal rate of spread of bacterial fruit blotch (BFB) versus Acidovorax citrulli inoculum load per seed under greenhouse conditions. Temporal spread was determined as final disease incidence (number of symptomatic seedlings/total number of seedlings)/18 days. Each data point is the mean rate of BFB progress for 10 replicates across three independent experiments $(n=30)$. and BFB transmission events across two-cell $\left(r^{2}=0.982 ; P<\right.$ 0.003; Fig. 3B) and three-cell $\left(r^{2}=0.916 ; P<0.001\right.$; Fig. 3C) distances. However, the slope of the line describing the relationship between BFB transmission and $A$. citrulli seed inoculum load was greatest for transmission events across a one-cell distance (7.78) followed by transmission across two-cell distances (3.49) and, subsequently, three-cell distances (1.66) (Fig. 3). As expected, shorter across-cell BFB seedling-to-seedling transmission events were more common than disease transmission across multiple-cell distances.

Risk of BFB transmission from asymptomatic seedlings exposed to $A$. citrulli in the greenhouse and transplanted into the field. In both field trials, BFB epidemics did not develop from

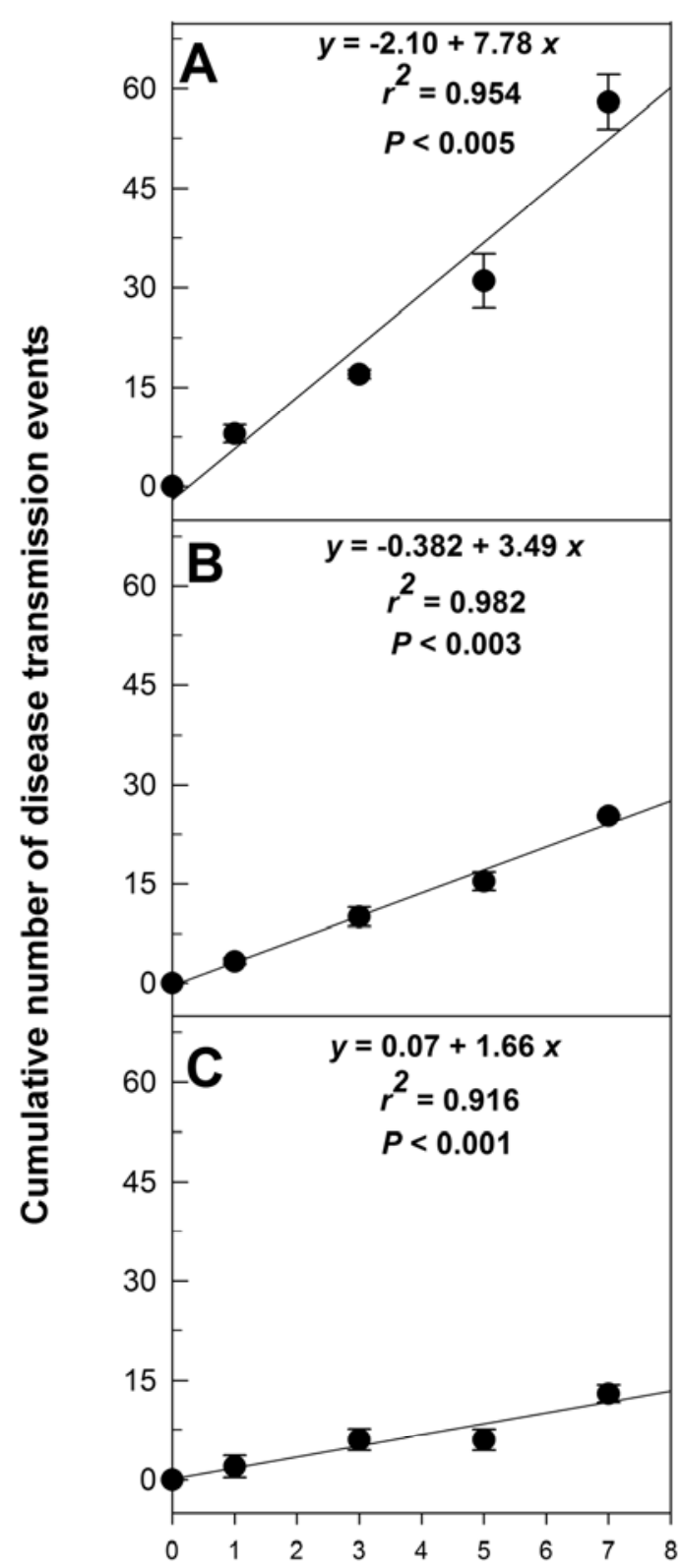

\section{A. citrulli seed inoculum load $\left(\log _{10} \mathrm{CFU} / \mathrm{seed}\right)$}

Fig. 3. Linear regression of spatial spread of bacterial fruit blotch (BFB) under greenhouse conditions versus Acidovorax citrulli inoculum load per seed over 18 days. An A. citrulli-inoculated watermelon seed was placed at the center of a 128cell tray and secondary spread was determined in terms of the cumulative number of cells across which the disease spread (BFB symptoms observed) from a seedling that developed from the inoculated seed to adjacent seedlings over $\mathbf{A}$, one-cell; B, two-cell; and C, three-cell distances. Each data point is the mean of 10 replicates across three independent experiments $(n=30)$. 
asymptomatic seedlings that were exposed to A. citrulli in the greenhouse. Additionally, $A$. citrulli was not recovered from plant tissue samples collected from the field plots in either year. During 2008 and 2009, Tifton, GA received a mean rainfall of $140.2 \mathrm{~cm}$ with 111 rainy days. The mean average temperature during this period was $26.4^{\circ} \mathrm{C}$. Although not excessively rainy, the field conditions were deemed conducive for BFB development because a natural BFB outbreak occurred in nearby Colquitt County in 2009.

Effect of $A$. citrulli seed inoculum load on detection by IMSreal time PCR assay. As expected, A. citrulli was not detected in negative control seedlots throughout this study. However, the mean detection frequencies for lots $(10,000$ seeds/lot $)$ with 1 seed containing $1 \times 10^{1}, 1 \times 10^{3}, 1 \times 10^{5}$, and $1 \times 10^{7} \mathrm{~A}$. citrulli $\mathrm{CFU}$ by IMS real-time PCR assay were 18.8, 75.0, 100, and 100\%, respectively (Fig. 4). The mean Ct values for IMS real-time PCR assays conducted on seed samples with seed inoculated with $1 \times 10^{1}, 1 \times$ $10^{3}, 1 \times 10^{5}$, and $1 \times 10^{7} \mathrm{CFU}$ were $34.01,32.84,31.72$, and 28.94 respectively (Table 2). Linear and nonlinear regression models were fitted, and the relationship of inoculum load per infested seed versus frequency of pathogen detection by IMS-PCR assay was described best by a two-parameter sigmoidal model $\left(R^{2}=0.997 ; P\right.$ $=0.0034)$. In contrast, a linear regression model fitted to this relationship was not statistically significant $(P=0.100)$.

A. citrulli seed inoculum threshold. The plot of detection frequency for $A$. citrulli-infested seedlots versus frequency of BFB seedling transmission revealed that, among the inoculum loads tested, the point closest to the theoretical optimum of $0 \%$ transmission and $100 \%$ detection frequency was a seed inoculum load of approximately $10^{3} \mathrm{CFU} / \mathrm{seed}$ (Fig. 5). For this seed inoculum load, the frequency of $A$. citrulli detection by IMS real-time PCR assay was $75.0 \%$ and the frequency of BFB seedling transmission was $46.6 \%$. At the next lowest seed inoculum load of approximately $10^{1} \mathrm{CFU} / \mathrm{seed}$, BFB seedling transmission occurred at $16.7 \%$ frequency but $A$. citrulli could only be detected in $18.8 \%$ of the assays.

\section{Discussion}

Overall, this study showed that, under greenhouse conditions, 1 watermelon seed infested with A. citrulli and mixed with 127 noninfested seeds could initiate a BFB epidemic in $>96 \%$ of the seedlots when the bacterial population on the infested seed was $\geq 1$ $\times 10^{5} \mathrm{CFU}$. Lots with one seed containing $1 \times 10^{3} \mathrm{CFU}$ also transmitted the disease but the frequency of transmission was reduced to $<50 \%$. Furthermore, although the data suggest that there is a reduced risk of BFB seedling transmission when a single seed

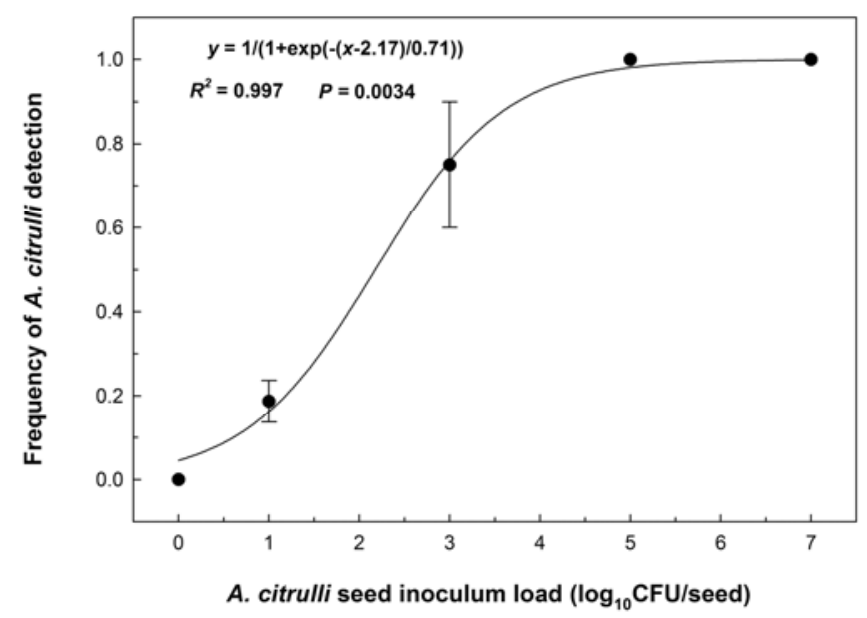

Fig. 4. Nonlinear regression analysis of Acidovorax citrulli detection frequency by immunomagnetic separation and real-time polymerase chain reaction assay versus inoculum load of $A$. citrulli per seed for inoculated watermelon seedlots $(10,000$ seeds) spiked with 1 seed infested at a range of CFU. Each data point represents the mean frequency of $A$. citrulli detection for four replicates in each of four independent experiments $(n=16)$. contains $\leq 10$ A. citrulli $\mathrm{CFU}$, zero tolerance may still be the best approach for BFB management in commercial transplant houses because, even for the lowest inoculum load tested, the frequency of seedling transmission still approached $20 \%$.

Initially, attempts to determine the effect of individual seed inoculum load on BFB seedling transmission were made with large seed samples (10,000 seeds/lot). However, due to greenhouse space constraints, only four replicates of each treatment could be evaluated in an experiment and there was significant cross-contamination among treatments. To avoid this problem, an experimental design was adopted whereby the experimental unit was a 128-cell seedling tray, in which one seed with a specific level of inoculum was planted per treatment. This design enabled more replicates of each treatment to be included per experiment. To generate infested seedlots, seed were inoculated individually by aspirating $A$. citrulli cell suspensions into each seed, followed by mixing 1 inoculated seed with 127 noninfested seeds. This technique enabled reproducible generation of seed with specific concentrations of bacterial cells. The efficiency of inoculation was $>90 \%$ for inoculum levels of $1 \times 10^{3}, 1 \times 10^{5}$, and $1 \times 10^{7} \mathrm{~A}$. citrulli CFU/seed. However, the inoculation efficiency fell to $0 \%$ as inoculum load decreased to $10 \mathrm{CFU} / \mathrm{seed}$. This may have been due to the dilution effect that made it impossible to recover CFU from seed with low inoculum loads but it is also possible that a proportion of the pathogen cells died or became nonviable (31) after inoculation, making recovery on solid agar medium impossible. This is even more likely considering that, after inoculation, seed were air dried at room temperature for $12 \mathrm{~h}$ before planting.

Table 2. Mean cycle threshold $(\mathrm{Ct})$ values generated by an immunomagnetic separation (IMS) and real-time polymerase chain reaction (PCR) assay for inoculated watermelon seedlots (10,000 seeds/lot) containing 1 seed with different levels of Acidovorax citrulli inoculum

\begin{tabular}{lc}
\hline Inoculum load $(\boldsymbol{A}$. citrulli CFU/seed) & ${\text { Mean } \mathbf{C t}^{\mathbf{a}}}^{\mathbf{a}}$ \\
\hline $10^{7}$ & $28.94 \pm 0.32$ \\
$10^{5}$ & $31.72 \pm 0.17$ \\
$10^{3}$ & $32.84 \pm 0.92$ \\
$10^{1}$ & $34.01 \pm 11.30$ \\
0 & 0 \\
Positive control $^{\mathrm{b}}$ & $27.82 \pm 0.62$ \\
\hline
\end{tabular}

a Mean \pm standard error of the $\mathrm{Ct}$ values of four replicate samples across four independent IMS real-time PCR assay experiments $(n=16)$.

b Positive control $=$ A . citrulli cell suspension at $10^{3} \mathrm{CFU} / \mathrm{ml}$.

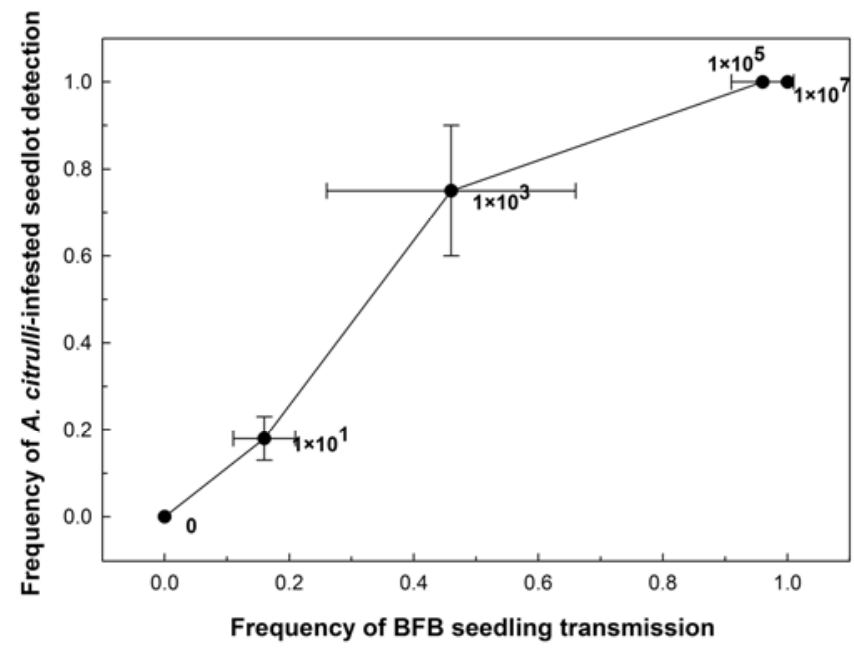

Fig. 5. Plot of the frequency of Acidovorax citrulli detection by an immunomagnetic separation real-time polymerase chain reaction assay versus bacterial fruit blotch (BFB) seedling transmission on watermelon for varying levels of $A$. citrulli seed inoculum load per seed. The number shown at each data point represents the concentration of $A$. citrulli inoculated per seed. Lines represent the standard errors of the mean frequencies. 
The ability of an IMS real-time PCR assay to detect A. citrulli in watermelon seedlots with one seed with varying levels of inoculum was tested. In a previous study, IMS-PCR was used to detect $A$. citrulli in 10,000-seed watermelon lots with 0.1 and $0.01 \%$ infested seed (37). However, the effect of seed inoculum load on pathogen detection was not considered. Although the IMS real-time PCR assay is not currently a standard BFB seed health assay, it has potential for commercial use. In this study, we observed a sigmoidal relationship between inoculum load per infested seed and frequency of pathogen detection by the IMS-PCR assay. For seedlots with the highest risk of BFB seedling transmission evaluated (lots with one seed infested with $10^{7}$ or $10^{5} \mathrm{~A}$. citrulli CFU), the IMS real-time PCR assay detected the bacterium in $100 \%$ of the samples. Lots with one seed containing $10^{3} \mathrm{CFU}$ of A. citrulli displayed lower frequency of BFB transmission (46.6\%) but still a relatively high level of pathogen detection $(75.0 \%)$ by the IMS real-time PCR assay. At $10 \mathrm{CFU} / \mathrm{seed}$, the lowest seed inoculum load tested, the frequencies of both BFB seedling transmission and pathogen detection dropped below $20 \%$, indicating that detection by seedling grow-out assay as well as by IMS-real-time PCR assay becomes unreliable at low inoculum loads.

Another aim of this study was to investigate the effect of $A$. citrulli seed inoculum load on temporal spread of BFB among watermelon seedlings in the greenhouse. The results indicated that, under greenhouse conditions without typical automated overhead irrigation, BFB developed faster from lots with one seed infested with $\geq 1 \times 10^{5} \mathrm{CFU}$ than from lots with one seed infested with $\leq 1 \times$ $10^{3} \mathrm{CFU}$. One possible explanation for this observation is the effect of seed inoculum load on incubation period. Gitaitis and Nilakhe (6) demonstrated the effect of inoculum load on incubation period for bacterial blight of cowpea by infiltrating 10-fold serial dilutions of seed wash from $X$. axonopodis pv. vignicola-infested seed samples into primary cowpea leaves. Seedlings were observed for symptom development and the inoculum dilution endpoint (highest dilution that led to symptom expression) was calculated. An incubation period of 5 to 20 days was required for symptom development in seed samples with $10^{-8}$ and $10^{-3}$ dilution endpoints. They also observed the highest disease incidence in the field from seedlots with the highest dilution endpoints.

A fourth goal of this study was to examine the influence of $A$. citrulli seed inoculum load on BFB spatial spread under greenhouse conditions. These data may be useful for developing strategies for managing BFB in transplant production facilities. Currently, when BFB occurs in commercial transplant houses, destruction of all exposed seedlings (seedlings growing in a greenhouse where an outbreak has occurred) is recommended (17). In many cases, however, growers cannot afford to destroy exposed seedlings because this may result in missed markets and significant economic losses. Alternatively, the growers often eliminate seedlings proximal to infection foci and continue to cultivate the remaining seedlings. Currently, there are no empirical data on the spatiotemporal spread of $A$. citrulli under transplant house conditions, or on how spread may be influenced by seed inoculum load. In this study, increased $A$. citrulli seed inoculum load led to an increase in spatial spread of BFB. Lots with one seed with high inoculum loads $\left(1 \times 10^{7}\right.$ or $1 \times 10^{5} \mathrm{~A}$. citrulli $\left.\mathrm{CFU}\right)$ resulted in a higher frequency of disease spread compared with lots with lower levels of inoculum $\left(1 \times 10^{3}\right.$ or $\left.1 \times 10^{1} \mathrm{CFU}\right)$. This could be explained by earlier disease onset and spread among seedlings in treatments with high inoculum density, providing increased likelihood of greater disease spread. Additionally, when asymptomatic seedlings that developed from seed inoculated with $0,1 \times 10^{1}$, and $1 \times 10^{3}$ CFU were planted in the field, no BFB symptoms developed. Although these seedlings were exposed to A. citrulli in the greenhouse, these observations suggest a low likelihood that the seedlings could initiate BFB epidemics under field conditions.

This is the first report of the effect of $A$. citrulli seed inoculum load on spatial spread of BFB under greenhouse conditions. Roberts et al. (23) described secondary spread of $X$. campestris pv. campestris from inoculated seed to noninoculated seedlings when planted in a greenhouse under overhead irrigation. Their results suggested that inoculum dose per seed and the watering regime (type and frequency of irrigation) affected both the proportion of plants with symptoms and the proportion of contaminated but asymptomatic plants. Seed harboring $3.6 \times 10^{3} \mathrm{CFU}$ of bacteria displayed significantly higher numbers of diseased plants than seed harboring $1.5 \times 10^{2} \mathrm{CFU}$. During the first 2 weeks after planting in their study, only the inoculum load per seed affected the proportion of symptomatic plants. However, by 3 weeks after planting, overhead irrigation, rather than inoculum load/seed, significantly influenced the proportion of symptomatic seedlings and secondary spread.

This study also evaluated the appropriateness of developing an A. citrulli seed inoculum threshold. Empirically determined seed inoculum thresholds have been successfully used to manage plant diseases $(5,8,25)$; however, thresholds have not been determined for many vegetable bacterial diseases, including BFB. To establish a seed inoculum threshold, correlation analyses should be made between levels of seed infestation and disease incidence in the field or greenhouse (16). From a practical perspective, all levels of seedborne inoculum may lead to some degree of disease transmission under conducive environmental conditions. Hence, in this study, the seed inoculum threshold for A. citrulli was considered to be the infestation level that resulted in low BFB incidence in the greenhouse while still having a high probability of pathogen detection by the IMS real-time PCR assay. A plot of the frequency of pathogen detection from an infested seedlot versus the frequency of seedling transmission revealed that approximately $10^{3} \mathrm{CFU} /$ seed was closest to this hypothetical inoculum threshold because this inoculum load was detected in $75.0 \%$ of the samples tested and resulted in transmission of BFB in approximately $46.6 \%$ of the seedlots tested. Practically, however, this threshold would be of no use because of the high disease transmission rate. Furthermore, seedlots with as little as one seed infested with 10 A. citrulli $\mathrm{CFU}$ transmitted BFB to seedlings in $16.7 \%$ of the seed samples, suggesting that, for effective BFB management, zero tolerance is appropriate.

To our knowledge, this is the first study of the effect of individual A. citrulli seed inoculum load on BFB seedling transmission and spread under greenhouse conditions. Data generated in this study should aid in BFB management in transplant production facilities and improve sample size determination for seed health testing. At present, results from BFB seed health assays are qualitative; however, based on this study, the risk of disease transmission is significantly influenced by seed inoculum load. This study may also have implications for interpretation of standard greenhouse seedling grow-out assay results (1). For example, seedlings from seedlots with low A. citrulli populations may not develop BFB symptoms within the standard 18-day test period. This may lead to false-negative results with important economic consequences. Although this study demonstrated that seed inoculum load has an important effect on BFB seedling transmission, it is impossible to determine the inoculum load of individual seed in a lot. At best, a quantitative, real-time PCR assay could enable estimation of pathogen population per seed sample, which may be of some practical use for predicting seedling disease transmission, even though such an assay does not take into account distribution of inoculum within a seedlot. Benefits may be gained from exploring the relationship between quantitative real-time PCR assay data, distribution of $A$. citrulli in naturally infested seedlots, and the risk of BFB seedling transmission.

\section{Acknowledgments}

This project was supported by the American Seed Trade Association Vegetable Permanent Research Fund. We thank Eurofins STA for material support and labor, L. Genzlinger and A. Castro Sparks for their valuable technical contributions, and R. Christiano for assistance with statistical analyses.

\section{Literature Cited}

1. Anonymous. 2004. National Seed Health System, Seed Health Methods, Vegetable Crop Methods. NSHS-USDA-APHIS, Ames, IA. 
2. Asis, S. M. P., Mariano, R. L. R., Silva-Hanlin, D. M. W., and Duart, V. 1999. Bacterial fruit blotch caused by Acidovorax avenae subsp. citrulli in melon, in the state of Rio Grande do Norte, Brazil. Fitopatol. Bras. 24:191.

3. Burdman, S., Kopelowitz, G., Kritzman. G., and Kots, N. 2005. Molecular, physiological, and host-range characterization of Acidovorax avenae subsp. citrulli isolates from watermelon and melon in Israel. Plant Dis. 89:13391347.

4. Demir, G. 1996. A new bacterial disease of watermelon in Turkey: bacterial fruit blotch of watermelon (Acidovorax avenae subsp. citrulli (Schaad et al.) Willems et al.). J. Turk. Phytopathol. 25:43-49.

5. Gabrielson, R. L. 1988. Inoculum thresholds of seedborne pathogens: fungi. Phytopathology 78:868-872.

6. Gitaitis, R. D., and Nilakhe, S. S. 1982. Detection of Xanthomonas campestris pv. vignicola in southern pea seed. Plant Dis. 75:1274-1278.

7. Gitaitis, R. D., and Walcott, R. R. 2008. The epidemiology and management of seedborne bacterial diseases. Annu. Rev. Phytopathol. 45:371-397.

8. Grogan, R. G. 1980. Control of lettuce mosaic with virus-free seed. Plant Dis. 64:446-449.

9. Ha, Y., Fessehaie, A., Ling, K. S., Wechter, W. P., and Walcott, R. R. 2009. Simultaneous detection of Acidovorax avenae subsp. citrulli and Didymella bryoniae in cucurbit seedlots using magnetic capture hybridization and realtime polymerase chain reaction. Phytopathology 99:666-678.

10. Hamm, P. B., Spink, D. S., Clough, G. H., and Mohan, K. S. 1997. First report of bacterial fruit blotch of watermelon in Oregon. Plant Dis. 81:113.

11. Hopkins, D. L., Cucuzza, J. D., and Watterson, J. C. 1996. Wet seed treatments for the control of bacterial fruit blotch of watermelon. Plant Dis. 80:529-532.

12. Hopkins, D. L., Lovic, B., Hilgren, J., and Thompson, C. M. 2003. Wet seed treatment with peroxyacetic acid for the control of bacterial fruit blotch and other seedborne diseases of watermelon. Plant Dis. 87:1495-1499.

13. Hopkins, D. L., and Thompson, C. M. 2002. Seed transmission of Acidovorax avenae subsp. citrulli in cucurbits. HortScience 37:924-926.

14. Jacobs, J. L., Damicone, J. P., and McCraw, B. D. 1992. First report of bacterial fruit blotch of watermelon in Oklahoma. Plant Dis. 76:1185.

15. Kennedy, B. W. 1969. Detection and distribution of Pseudomonas glycinea in soyabean. Phytopathology 59:1618-1619.

16. Kuan, T. L. 1988. Inoculum thresholds of seedborne pathogens. Phytopathology 78:867-868.

17. Latin, R. X., and Hopkins, D. L. 1995. Bacterial fruit blotch of watermelon - the hypothetical exam question becomes reality. Plant Dis. 79:761765.

18. Martin, H. L., and Harlock, C. M. 2002. First report of Acidovorax avenae subsp. citrulli as a pathogen of Gramma in Australia. Plant Dis. 86:1406.

19. Maude, R. B. 1996. Seedborne Diseases and Their Control. Principles and Practices. CAB International, Wallingford, UK.

20. McGee, D. C. 1995. Epidemiological approach to disease management through seed technology. Annu. Rev. Phytopathol. 33:445-466.

21. Morrison, R. H. 1999. Sampling in seed health testing. Phytopathology 89:1084-1087.

22. Rane, K. K., and Latin, R. X. 1992. Bacterial fruit blotch of watermelon: association of the pathogen with seed. Plant Dis. 76:509-512.

23. Roberts, S. J., Hiltunen, L. H., Hunter, P. J., and Brough, J. 1999. Transmission of seed to seedling and secondary spread of Xanthomonas campestris pv. campestris in Brasicca transplants: effects of dose and watering regime. Eur. J. Plant Pathol. 105:879-889.

24. Roberts, S. J., Ridout, M. S., Peach, L., and Brough, J. 1996. Transmission of pea bacterial blight (Pseudomonas syringae subsp. pisi) from seed to seedling: effects of inoculum dose, inoculation method, temperature, and soil moisture. J. Appl. Bacteriol. 81:65-72.

25. Russell, T. S. 1988. Inoculum thresholds of seedborne pathogens: some aspects of sampling and statistics in seed health testing and the establishment of threshold levels. Phytopathology 78:880-881.

26. Schaad, N. W. 1988. Inoculum thresholds of seedborne pathogens: bacteria. Phytopathology 78:872-875.

27. Schaad, N. W., Postnikova, E., and Randhawa, P. 2003. Emergence of Acidovorax avenae subsp. citrulli as a crop-threatening disease of watermelon and melon. Pages 573-581 in: Pseudomonas syringae and Related Pathogens-Biology and Genetics. N. S. Iacobellis, A. Collmer, S. W. Hutcheson, J. W. Mansfield, C. E. Morris, J. Murillo, N. W. Schaad, D. E. Stead, G. Surico, and M. S. Ullrich, eds. Kluwer, Dordrecht, The Netherlands.

28. Schaad, N. W., Postnikova, E., Sechler, A., Claflin, L. E., Vidaver, A. K., Jones, J. B., Agarkova, I., Ignatov, A., Dickstein, E., and Ramundo, B. A. 2008. Reclassification of subspecies of Acidovorax avenae as A. avenae (Manns 1905) emend., A. cattleyae (Pavarino, 1911) comb. nov., A. citrulli (Schaad et al., 1978) comb. nov., and proposal of A. oryzae sp. nov. Syst. Appl. Microbiol. 31:434-446.

29. Schaad, N. W., Sitterly, W. R., and Humaydan, H. 1980. Relationship of incidence of seedborne Xanthomonas campestris to black rot of crucifers. Plant Dis. 64:91-92.

30. Schaad, N. W., Sowell, G., Jr., Goth, R. W., Colwell, R. R., and Webb, R. E. 1978. Pseudomonas pseudoalcaligenes subsp. citrulli subsp. nov. Int. J. Syst. Bacteriol. 28:117-125

31. Schuster, M. L., and Coyne, D. P. 1974. Survival mechanisms of phytopathogenic bacteria. Annu. Rev. Phytopathol. 12:199-122.

32. Shirakawa, T., Kikuchi, S., Kato, T., Abiko, K., and Kaiwa, A. 2000. Occurrence of watermelon fruit blotch in Japan. Jpn. J. Plant Pathol. 66:223-231.

33. Somodi, G. C., Jones, J. B., Hopkins, D. L., Stall, R. E., Kucharek, T. A., Hodge, N. C., and Watterson, J. C. 1991. Occurrence of bacterial fruit blotch in Florida. Plant Dis. 75:1053-1056.

34. Sowell, G., and Schaad, N. W. 1979. Pseudomonas pseudoalcaligenes subsp. citrulli on watermelon-seed transmission and resistance of plant introductions. Plant Dis. Rep. 63:437-441.

35. Umesh, K. C., Davis, R. M., and Gilbertson, R. L. 1998. Seed contamination thresholds for development of carrot bacterial blight caused by Xanthomonas campestris pv. carotae. Plant Dis. 82:1271-1275.

36. Walcott, R. R. 2008. Integrated pest management of bacterial fruit blotch in cucurbits. Pages 191-209 in: Integrated Management of Diseases Caused by Fungi, Phytoplasma and Bacteria. A. Ciancio and K. G. Mukerji, eds Springer, New York.

37. Walcott, R. R., Castro, A. C., Fessehaie, A., and Ling, K. 2006. Progress towards a commercial PCR-based seed assay for Acidovorax avenae subsp. citrulli. Seed Sci. Technol. 34:101-116.

38. Walcott, R. R., and Gitaitis, R. D. 2000. Detection of Acidovorax avenae subsp. citrulli in watermelon seed using immunomagnetic separation and the polymerase chain reaction, Plant Dis. 84:470-474.

39. Webb, R. E., and Goth, R. W. 1965. A seedborne bacterium isolated from watermelon. Plant Dis. Rep. 49:818-821.

40. Willems, A., Goor, M., Thielemans, S., Gillis, M., Kersters, K., and DeLey, J. 1992. Transfer of several phytopathogenic Pseudomonas species to Acidovorax as Acidovorax avenae subsp. avenae subsp. nov., comb. nov., Acidovorax avenae subsp. citrulli, Acidovorax avenae subsp. cattleyae, and Acidovorax konjaci. Int. J. Syst. Bacteriol. 42:107-119.

41. Yuen, J., Twengstrom, E., and Sigvald, R. 1996. Calibration and verification of risk algorithms using logistic regression. Eur. J. Plant Pathol. 102:847854. 